\title{
A testmozgás szerepe az egészségügyi dolgozók egészségfejlesztésében
}

\author{
Terebessy András dr. ${ }^{1}$ - Matyasovszky Melinda dr. ${ }^{1}$ - Horváth Ferenc dr. ${ }^{1}$ \\ Horosz Áron ${ }^{2}$. Juhász Irén ${ }^{3}$. Győrffy Zsuzsa dr. ${ }^{4}$ \\ Semmelweis Egyetem, ${ }^{1}$ Általános Orvostudományi Kar, Népegészségtani Intézet, \\ ${ }^{2}$ Alumni Igazgatóság, \\ ${ }^{3}$ Múszaki Főigazgatóság, ${ }^{4}$ Általános Orvostudományi Kar, Magatartástudományi Intézet, Budapest
}

\begin{abstract}
Bevezetés: Az egészségügyben dolgozó orvosok, nővérek és egyéb szakemberek egészségi állapota a munkában töltött évekkel romlik, ami befolyást gyakorolhat az általuk végzett munka minőségére is. Az egészségügyi dolgozók egészségfejlesztése így nem csupán munkahelyi prevenciós programként, hanem az egészségügyi ellátás minőségét javító intézkedésként is felfogható. Célkitüzés: Egészségi alapállapot-felmérést követően intervenciós egészségfejlesztési program hatékonyságának mérése egészségügyi dolgozók körében. Módszer: A vizsgálat elején és végén kérdőíves és fizikaiállapot-felmérés történt. Az intervenciós csoport tagjai igénybe vehettek fitneszszolgáltatásokat, pszichológiai szakember segítségét, dietetikai tanácsadást és fogászati konzultációt. Eredmények: A 12 hónapon át tartó vizsgálat 79 dolgozó részvételével indult, akik maguk dönthették el, hogy intervenciós vagy kontrollcsoportba kerüljenek. A vizsgálat végén az intervenciós csoportban a haskörfogat szignifikáns csökkenését és a 12 perc alatt futott táv növekedését észlelték. Következtetések: Az eredmények igazolni látszanak az aktív életmóddal együtt járó rendszeres testmozgás kedvező hatását mind a fizikai teljesítőképesség növekedésében, mind pedig a testalkat változásában. Orv. Hetil., 2016, 157(39), 1563-1570.
\end{abstract}

Kulcsszavak: egészségi állapot, életmód, egészségügyi dolgozók, egészségfelmérés

\section{The role of physical activity in health promotion of healthcare workers}

Introduction: The health status of doctors, nurses and any other professionals working in the healthcare sector influences the quality of their work. Therefore, health promotion of healthcare workers is not only an occupational health program but it can be considered as an action towards improving the quality of care. Aim: The current study was designed to assess the efficacy of a health promotion intervention among healthcare workers after health status assessment. Method: Before and after the intervention a self-assessment questionnaire-based health survey and physical status examination were performed. Members of the intervention group were offered to use fitness facilities, professional psychological help, dietary counselling, and dental consultation. Results: The intervention program lasted for 12 months with the participation of 79 health care professionals (based on their decision being in the intervention or in the control group). Significant decrease was found in the abdominal perimeter in participants of the intervention group and they ran a longer distance on the 12 minute-long-run test at the end of the study. Conclusions: The positive effect of regular physical exercise as part of active lifestyle has been demonstrated not only in the increase of physical capacity, but in the change of body shape, as well.

Keywords: health status, life style, health personnel, health surveys

Terebessy, A., Matyasovszky, M., Horváth, F., Horosz, Á., Juhász, I., Györffy, Zs. [The role of physical activity in health promotion of healthcare workers]. Orv. Hetil., 2016, 157(39), 1563-1570.

(Beérkezett: 2016. június 6.; elfogadva: 2016. július 19.)

Magyarországon a Központi Statisztikai Hivatal nyilvántartása szerint mintegy 36 ezer aktív orvos dolgozik [1]. Mellettük az ágazatban további 50 ezer ápoló és 50 ezer egyéb foglalkozású egészségügyi szakdolgozó végez munkát. Ez mintegy 140 ezer embert jelent, a 20-59 év közötti lakossághoz viszonyítva (5,7 millió fó) annak 
2,35\%-át, azaz az egészségügy az egyik legnagyobb létszámmal dolgozó szolgáltatás; a munkavállalók egészségi állapotának megőrzése kulcsfontosságú feladat lenne [2].

Az egészségügyi munkakörnyezet fizikai, kémiai, biológiai és ergonómiai veszélyt is jelenthet a munkavállaló számára, de ezen túlmenően a pszichoszociális kockázatokat is figyelembe kell venni [3]. Közismert például, hogy a hosszan tartó mútéti beavatkozások rendkívüli megterhelést jelentenek a mozgató szervrendszer számára, de az már kevésbé nyilvánvaló, hogy a növekvő adminisztrációs kötelezettségek miatt még az abszolút manuális típusú szakmákban tevékenykedőknek is jelentős időt kell eltölteni ,irodai típusú”, ülő munkával, de ugyanide sorolható többek között az ápolószemélyzet betegmozgató feladatköre is, mint potenciális probléma [4].

A gyógyítópályát választók mentális egészségi mutatói lényegesen rosszabbak a társadalom egyéb, velük összemérhetô rétegeinél $[5,6]$. Az egészségügyi dolgozókra fokozottan jellemző a kiégés és következményei, az érzelmi kimerülés, elszemélytelenedés és a teljesítmény csökkenése. Egészségügyi munkahelyeken nagyon sok helyütt megkövetelt a váltott mûszakban végzett munka, ez egyaránt jelenthet kardiometabolikus kockázatnövekedést, fokozhatja az alvászavarok és a depresszió gyakoriságát is [7-9]. Egyéb, a mentális egészség romlását előidéző, háttérben álló lehetséges okok például a folyamatosan és egyre kiszámíthatatlanabbul átalakuló munkakörnyezet, a társadalmi, szakmai és anyagi megbecsülés csökkenése - sokszor teljes hiánya -, az ezzel szemben álló óriási erkölcsi és (mind büntető, mind polgári) jogi felelősség, a félelem a hibáktól és a kártérítési perektól $[10,11]$.

A kórházak egészség fejlesztő-megőrző tevékenységet nem vagy csak ritkán végeznek - még saját munkavállalóik körében is. Közismerten ritka, hogy a kórházakban - de tulajdonképpen a teljes egészségügyi ágazatban csupán nyolc órát töltsenek munkával a munkavállalók. A túlságosan hosszúra nyúló munkaidő, a túlórák, illetve másodállások időhiányhoz, közvetetten pedig kevés egészségmegőrzésre fordított időhöz vezetnek, így ebből a szempontból az egészségügyi dolgozókat kedvezőtlen helyzetben lévő populációnak tekinthetjük. Kiemelten fontosnak tartjuk az egészségügyi dolgozók számára az egészségfejlesztést, ezen belül is külön a testedzést, mint az egyik legfontosabb betegségmegelőző tevékenységet, mert a rendszeres testmozgás nemcsak edzettebbé, ellenállóbbá tesz a betegségekkel szemben, de példát is mutathat a környezetnek, pácienseknek.

\section{Módszer}

$\mathrm{Az}$ „Egészségügyiek egészségéért” projekt (rövid neve: EE projekt) a Semmelweis Egyetem Alumni Igazgatóságának kezdeményezésére a Népegészségtani Intézet és a Magatartástudományi Intézet közremúködésével indult 2013 elején. Kutatásunk céljaként 120 fö egészségi álla- potának két alkalommal történő, egyéves eltéréssel végrehajtott komplex vizsgálatát tûztük ki, ideértve táplálkozási és egyéb életmódbeli szokások felmérését, edzettségi állapot vizsgálatát, valamint biomedikális adatok felvételét. Minden jelentkezőnek felajánlottuk a választás lehetőségét intervenciós, illetve kontrollcsoport között. Az előbbi csoport tagjai önköltséges egészségfejlesztési szolgáltatásokat vehettek igénybe 12 hónapon keresztül, míg a kontrollcsoport tagjai csak a kezdő és záró állapotfelméréseket vállalták. Kutatásunkat a Semmelweis Egyetem Regionális, Intézményi Tudományos és Kutatásetikai Bizottsága 156/2012 számú határozatában jóváhagyta.

Minden résztvevő átesett általános orvosi fizikális vizsgálaton, amely kiegészült a szomatometriás mérésekkel, úgymint magasságmérés, haskörfogatmérés, derék-csípő arány vizsgálata, testtömeg-meghatározás, testzsír- és vázizomtömeg-mérés, ezenkívül a hasi zsírfelület vizsgálata és a BMI számítása is megtörtént. Az edzettségi állapot felmérése a 12 perces Cooper-teszt segítségével történt. Azok eredményét, akik nem tudtak ennyi ideig futni, átlagsebességük alapján 12 percre vetítettük [12].

A résztevők kérdőíves adatfelvétel során beszámoltak táplálkozási, dohányzási, alkoholfogyasztási szokásaikról, valamint válaszoltak a fizikai és lelki egészségre vonatkozó kérdésekre is. Kérdő́ivünket saját kérdések és más kutatócsoportok által korábban már használt eszközök egybeszerkesztésével alakítottuk ki. Kérdéseinkre a válaszadók elektronikus, önkitöltő módon felelhettek.

A táplálkozás és testmozgás felméréséhez egy kanadai kutatócsoport által kifejlesztett kérdő́iv módosított változatát használtuk [13]. A válaszadóknak számot kellett adniuk különböző élelmiszercsoportokat érintő fogyasztási szokásaikról. Az eredeti kérdőív módszertanának megfelelően a zöldség, gyümölcs és rosttartalmú ételek fogyasztási gyakoriságait pontértékre konvertáltuk, majd összeadtuk. Így minden válaszadó táplálkozási szokásait 0-15 közötti pontértékkel jellemeztük (diétapontszám), a magasabb pontszám az ajánlásokhoz közelebb álló táplálkozási mintát jelez. Testmozgás tekintetében szintén az eredeti kérdốív módszertanának megfelelően három kategóriát különítettünk el: könnyú testedzés (házimunka, kényelmes séta, hobbikertészkedés); közepes testmozgás (gyors séta, úszás, kerékpározás, tánc); megerőltető testmozgás (futás, aerobik, csapat- és versenysportok). Pontérték-konverzió után a kérdésre adott válaszok alapján a fizikai aktivitást $0-24$ közötti pontszámmal jellemeztük (sportpontszám), a magasabb pontszám a testmozgási ajánlásokhoz közelebb álló mozgásmintát jelez.

Dohányzásra 8 kérdés vonatkozott, közülük az első az aktuális, a második a múltbéli dohányzásra irányult. További hat kérdés - a Fagerström-teszt szerint - az aktuálisan dohányzókra vonatkozott [14].

Válaszadóink alkoholfogyasztásukat nyitott kérdésekre adott válaszokkal jellemezhették, ahol megadhatták az italféleségeket és ezek fogyasztási gyakoriságát. 
Része volt még az állapotfelmérésnek az egészségi állapot önértékelt jellemzése a leginkább széles körben használt, öt válaszlehetőséget tartalmazó kérdéssel ( „Milyennek ítéli meg egészségi állapotát most?”), illetve az SF-36 kérdőívvel is [15]. A 36 zárt jellegű kérdéshez kategóriaváltozók tartoznak, az értékelőeszköz segítségével a válaszok 0-100-ig terjedő numerikus skálára konvertálhatók, a magasabb érték kedvezőbb állapotot jelez. A konverzió után összesen 8 kategóriában (fizikai teljesítmény, korlátozott tevékenység fizikai állapot miatt, korlátozott tevékenység érzelmi állapot miatt, energiaállapot, érzelmi jóllét, közösségi funkciók ellátása, testi fájdalom, egészségi állapot általában) határozható meg egy-egy válaszadó önértékelt egészségi állapota.

\section{Intervenciós lehetosségek}

$\mathrm{Az}$ intervenciós csoport tagjai számára együttmúködési szerződés alapján a projekt önköltséges intervenciós lehetőségeket ajánlott, amelyek közül a résztvevők szabadon választhattak az alábbi lehetőségek közül:

Sportkártya: Használatával havi 8 alkalommal nyílt lehetőség sportolásra. A résztvevő a számára a területileg leginkább megfelelő, illetve legjobban tetsző mozgásformát választhatta.

Kommunikációs, kiégésprevenciós és stresszkezelő tréningek: Csoportos képzések formájában pszichológus szakemberek vezették, kifejezetten az egészségügyi munkára fókuszálva.

Személyes pszichológiai tanácsadás: Ötalkalmas egyéni életvezetési tanácsadás, képzett pszichoterapeuta vezetésével.

A programban szereplők használhattak online dietetikai kockázatbecslő és tanácsadó rendszert, továbbá lehetőség adódott fogászati állapotfelmérésre és tanácsadásra is.

\section{Statisztikai elemzés}

Minden esetben a legmegfelelőbb statisztikai módszer kiválasztását céloztuk meg eredményeink elemzése során. Biomedikális, illetve fittségi vizsgálataink végén folytonos skálázású adatokat, kérdőíves felmérésünknek köszönhetően pedig megoszlási arányokat, illetve pozitív egész számokra konvertálható skálákat kaptunk. Ahol lehetséges volt, minden esetben meghatároztuk az átlagot, a szórást, valamint a mediánt is, figyelembe véve az adatok eloszlásának normalitását is. Nominális, illetve ordinális változóink esetén a válaszok gyakoriságát, megoszlási arányait vizsgáltuk elemzéseink kezdetén. Normáleloszlás esetében két numerikus változó összehasonlítására kétmintás t-próbát végeztünk. Nem normáleloszlású változóink esetén a Mann-Whitney-próbát alkalmaztuk a feltételezett összefüggések feltárására. A változások ellenőrzésére normáleloszláskor párosított t-próbát, nem normáleloszlás esetén Wilcoxon-tesztet hajtottunk végre. Nominális és ordinális változóink biná- ris összehasonlítása kereszttáblás elemzésekkel, $\chi^{2}$ próbával történt. A statisztikai próbák eredményét p <0,05 érték esetén fogadtuk el szignifikánsnak, 95\%-os konfidenciaintervallum meghatározása mellett.

\section{Eredmények}

Vizsgálatunkba mindösszesen 79 fó jelentkezett, az intervenciós csoportba 33-an (26 nő, 7 férfi), míg a kontrollcsoportba 46-an (41 nö, 5 férfi). Nem mindenki vett részt a kezdeti állapotfelmérés minden elemében, a projekt 12 hónapja során pedig sokan kiléptek a programból, illetve a záró felmérésekre nem jöttek el, a pontos elemszámot az eredményeknél ezért mindig külön is feltüntettük.

\section{A kezdeti állapotfelmérés eredményei}

Internetes demográfiai, illetve életmód és önértékelt egészségi állapot kérdőívünket a vizsgálat kezdetén 77 fó töltötte ki, 85,7\%-uk ( 66 fó) nő és 14,3\%-uk ( 11 fö) férfi volt. A minta áltagéletkora 44,42 év (SD: 11,98), mediánja 45 év volt. A program kezdetekor a legfiatalabb résztvevő 24, a legidősebb pedig 69 esztendős volt. A nők átlagéletkora 44,83 év (SD: 11,91), a férfiak átlagéletkora 41,91 év (SD: 12,67) volt.

Legmagasabb iskolai végzettségnek válaszadóink 15,6\%-a gimnáziumi vagy szakközépiskolai érettségit, míg 84,4\%-a egyetemi vagy főiskolai diplomát adott meg. A válaszadók 50,7\%-a (38 fő) klinikai, kórházi, szakrendelői vagy körzeti orvosként dolgozott. A megkérdezettek 94,7\%-ának munkájához rendszeresen szükséges számítógépet használnia, naponta munkaügyben átlagosan 4,14 órát (SD: 2,01) töltöttek a számítógép képernyője előtt, míg szabadidejükben átlagban 1,22 órát számítógépeztek (SD: 0,64). Az átlagos napi televíziónézéssel eltöltött idő 1,02 óra volt (SD: 0,72).

$\mathrm{Az}$ ajánlásoknak megfelelő, napi három alkalommal javasolt zöldség- és gyümölcsfogyasztást a kérdőívet kitöltők csak igen kis arányban követték: 3,9\% fogyaszt napi szinten többször zöldséget, míg gyümölcsöt 18,2\%uk. Rostdús ételeket az ajánlásnak megfelelően mindöszszesen $9,1 \%$ fogyaszt. Halat a résztvevők közül senki sem fogyasztott napi gyakorisággal: $67,5 \%$ ritkábban, mint hetente, $22,1 \%$ hetente egyszer, míg 10,4\%-uk hetente 2-3-szor választja a halat étkezése során. Válaszadóink 1,3\%-a fogyaszt naponta többször vörös húst, illetve napi rendszerességgel 7,8\%-uk, míg baromfihúst naponta többször senki sem, naponta pedig 9,1\%-uk.

A módszertani részben bemutatott módon számított diétapontszám átlaga 7,03-nak, mediánja 7-nek adódott, míg a sportpontszám ugyanezen értékei 10,74, illetve 12. A sportpontszám számításához használt testmozgási gyakoriságok megoszlását az 1. táblázat mutatja.

A válaszadók 1,3\%-a napi rendszerességgel, 6,5\%-uk alkalmanként dohányzik, 16,9\%-uk már teljesen leszokott róla és 75,3\%-uk soha nem is volt dohányos. Alko- 
Testmozgásra vonatkozó prevalenciaadatok a kezdeti állapotfelméréskor

\begin{tabular}{llll}
\hline Testmozgás & $\begin{array}{l}\text { Könnyú } \\
\text { testmozgást } \\
\text { végzők } \\
\text { megoszlása, } \\
\mathrm{n}(\%)\end{array}$ & $\begin{array}{l}\text { Közepes } \\
\text { testmozgást } \\
\text { végzők } \\
\text { megoszlása, } \\
\mathrm{n}(\%)\end{array}$ & $\begin{array}{l}\text { Megeróltető } \\
\text { testmozgást } \\
\text { végzók } \\
\text { megoszlása, } \\
\mathrm{n}(\%)\end{array}$ \\
\hline $\begin{array}{l}\text { Soha } \\
\begin{array}{l}\text { Heti egy-két } \\
\text { alkalommal }\end{array}\end{array}$ & $33(42,8)$ & $46(59,7)$ & $29(38,2)$ \\
$\begin{array}{l}\text { Heti három-négy } \\
\text { alkalommal }\end{array}$ & $24(31,2)$ & $13(16,9)$ & $5(6,6)$ \\
$\begin{array}{l}\text { Heti öt-hét } \\
\text { alkalommal }\end{array}$ & $20(26,0)$ & $5(6,5)$ & $1(1,3)$ \\
\hline Összesen & $77(100)$ & $77(100)$ & $76(100)$ \\
\hline
\end{tabular}

Egy válaszadó többféle testmozgástípust is megjelölhetett.

2. táblázat $\mid$ Az SF-36 kérdő́iv 8 komponensében kapott eredmények a kezdeti állapotfelméréskor

\begin{tabular}{lll|lc}
\hline & $\begin{array}{c}\text { Nók } \\
\text { Átlag }\end{array}$ & SD & Férfiak & \\
& Átlag & \multicolumn{1}{c}{ SD } \\
\hline Fizikai múködés (SF1) & 93,25 & 7,53 & 94,09 & 7,01 \\
Fizikai szerep (SF2) & 81,35 & 33,29 & 90,90 & 23,11 \\
Érzelmi szerep (SF3) & 64,55 & 37,80 & 75,76 & 42,40 \\
Vitalitás (SF4) & 60,30 & 20,77 & 70,00 & 22,25 \\
Mentális egészség (SF5) & 72,90 & 16,30 & 76,00 & 24,00 \\
Szociális múködés (SF6) & 75,00 & 23,82 & 75,00 & 26,22 \\
Testi fájdalom (SF7) & 84,24 & 20,29 & 83,86 & 27,21 \\
Általános egészség (SF8) & 69,23 & 18,86 & 58,64 & 20,99 \\
\hline
\end{tabular}

holt a válaszadók 87,7\%-a fogyaszt legalább havi rendszerességgel. Az egy alkalommal átlagosan elfogyasztott italmennyiség 1,53 pohár volt (SD: 0,78$)$, úgynevezett rohamivást (egy alkalommal egyszerre több mint 5 ital elfogyasztása) nem regisztráltunk.

Az eszközösen mérhető paraméterek vizsgálatában 53 fö (42 nő, 11 férfi) vett részt. Az átlagos szisztolés vérnyomás 124,38 Hgmm-nek adódott (SD: 17,77). A nők átlagos szisztolés vérnyomása 121,22 Hgmm (SD: 17,82), míg a férfiaké 134,70 $\mathrm{Hgmm}$ (SD: 14,42) volt $(\mathrm{p}=0,031) \mathrm{Az}$ átlagos diasztolés vérnyomás 80,92 Hgmm volt (SD: 12,34). A nők átlagos diasztolés vérnyomása 78,34 Hgmm (SD:10,98), míg a férfiaké 88,90 $\operatorname{Hgmm}(\mathrm{SD}: 16,56)$, szignifikánsan magasabb volt $(\mathrm{p}=$ $0,007)$. Kóros szisztolés $(>140)$ és diasztolés $(>90)$ értéket is 12 esetben mértünk. Az átlagos pulzusszám $73,07 /$ perc (SD: 8,88), a medián $71 /$ perc volt. A nők $(72,90 /$ perc, SD: 8,80$)$ és a férfiak $(72,89 /$ perc, SD: 10,42) pulzusszáma nem különbözött egymástól szignifikánsan.

A BMI-értékek tekintetében is szignifikáns különbség volt a két csoport között, a férfiaké $29,70 \mathrm{~kg} / \mathrm{m}^{2}$ (SD: $7,07)$, míg a nóké $25,03 \mathrm{~kg} / \mathrm{m}^{2}(\mathrm{SD}: 5,03)$ volt $(\mathrm{p}=$ $0,019)$. Az átlagos BMI $25,91 \mathrm{~kg} / \mathrm{m}^{2}$ (SD: 5,63 ) volt, a normáltartomány felső határát 23 fó haladta meg. A nők haskörfogata $89,98 \mathrm{~cm}$ (SD: 14,2), míg a férfiaké 105,40 cm (SD: 15,48) volt. A valós, illetve számított Cooperteszt összevont adatai alapján a fizikai állapotfelmérésen 12 perc alatt a résztvevők $(n=46)$ átlagosan 1907 métert futottak (SD: 475,77; minimum: 995,9; maximum: 2800).

$\mathrm{Az}$ önértékelt egészségi állapot 8 komponensének eredményeit férfi-nő bontásban a 2. táblázat mutatja be. A két nem értékei között nem találtunk szignifikáns különbséget.

\section{A változások elemzései}

A projekt zárásakor és kezdetekor kapott eredményeket az intervenciós és a kontrollcsoport tekintetében hasonlítottuk össze. Bár mind a két csoportban sok esetben tapasztaltunk különbséget a kezdeti és a végső állapot között, statisztikai módszerekkel is igazolható (szignifikáns) változást a két időpont között csak igen kevés esetben regisztráltunk. A diétapontszám és a sportpontszám értéke a projekt kezdeti és záró pontja között az intervenciós csoportban szignifikánsan változott, kedvező irányba. A diétapontszámot 26 fó esetén tudtuk mind a két esetben számítani, kezdéskor az átlag 7,88, záráskor 8,85 volt $(\mathrm{Z}=-1,975, \mathrm{p}=0,048)$, míg a sportpontszámot 24 esetben, kezdő átlag: 10,58; záró: 13,12

3. táblázat |Az intervenciós és a kontrollcsoport változásai az SF-36 kérdőív 8 komponensében

\begin{tabular}{|c|c|c|c|c|c|c|c|c|}
\hline Interv. & SF1 & SF2 & SF3 & SF4 & SF5 & SF6 & SF7 & SF8 \\
\hline $\mathrm{n}$ & 17 & 25 & 26 & 24 & 24 & 26 & 26 & 24 \\
\hline $\mathrm{Z}$ & $-1,919$ &,- 647 & $-2,041$ &,- 382 & $-2,125$ & $-1,302$ &,- 285 & $-1,973$ \\
\hline p-érték & 0,055 & 0,518 & 0,041 & 0,702 & 0,034 & 0,193 & 0,776 & 0,048 \\
\hline Kontroll & SF1 & SF2 & SF3 & SF4 & SF5 & SF6 & SF7 & SF8 \\
\hline $\mathrm{n}$ & 19 & 25 & 24 & 25 & 24 & 26 & 26 & 25 \\
\hline $\mathrm{Z}$ & $-3,022$ & $-2,364$ & $-1,933$ & $-2,410$ &,- 342 & $-2,079$ & $-1,143$ & $-2,363$ \\
\hline p-érték & 0,003 & 0,018 & 0,053 & 0,016 & 0,732 & 0,038 & 0,253 & 0,018 \\
\hline
\end{tabular}



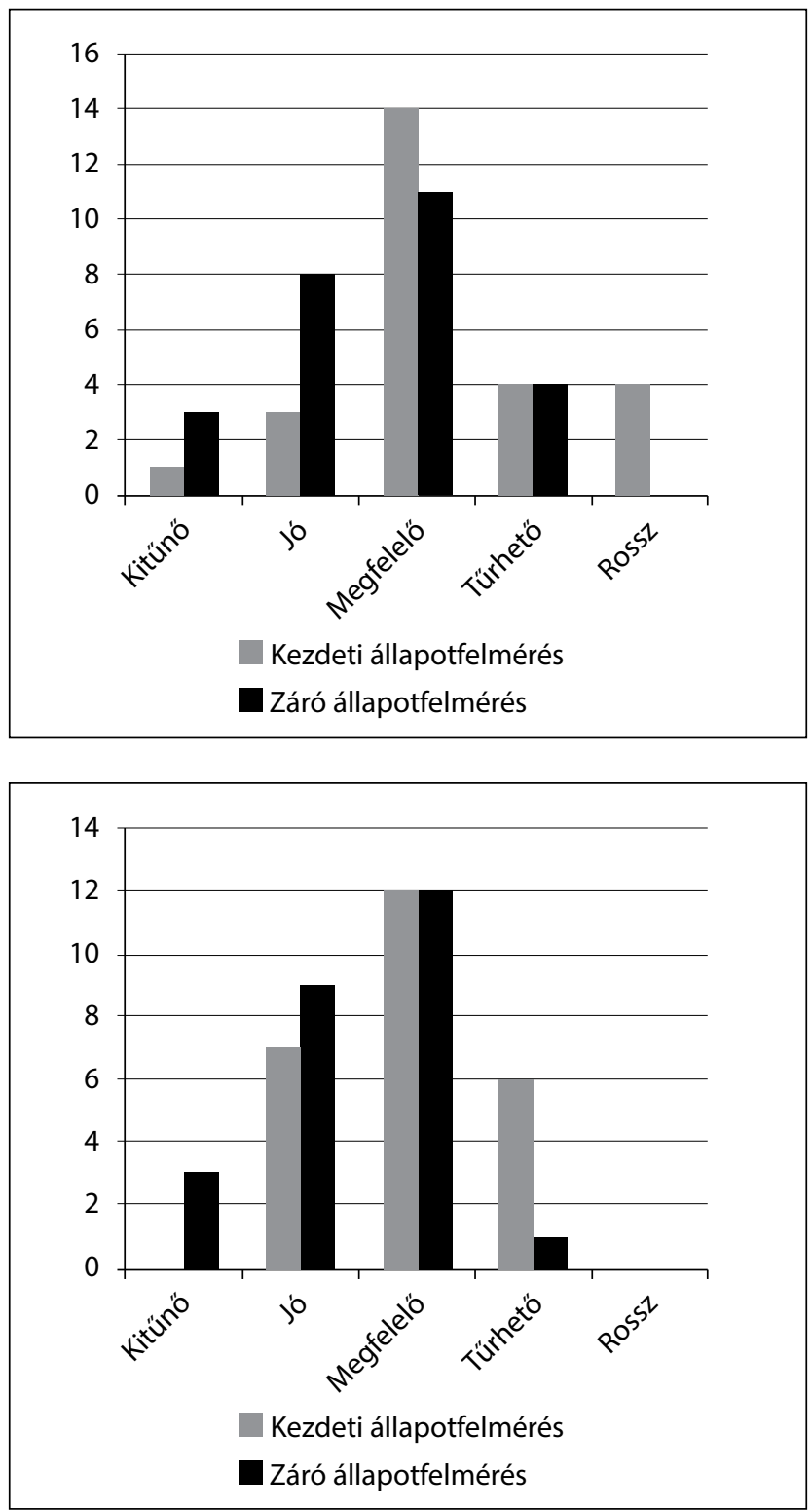

1. ábra A „Milyennek ítéli meg egészségi állapotát?” kérdésre adott vá-
laszok megoszlása az intervenciós (fent) és kontrollcsoport
(lent) résztvevőinek körében
Megjegyzés: az ábra felső részében a „Rossz” kategória felett a
fekete oszlop, az alsó részében a „Kitűnő” felett a szürke, a
„Rossz” kategória felett mindkét oszlop szándékosan hiányzik,
mert ilyen kategóriába nem sorolta magát senki.

$(\mathrm{Z}=-2,386, \mathrm{p}=0,017)$. Kontrollcsoportunkban szignifikáns változás a sportpontszámban volt mérhető, 23 válaszadó adatai alapján a kezdő átlag 11,04, a záró 13,00 volt $(\mathrm{Z}=-2,231, \mathrm{p}=0,023)$. Intervenciós csoportunkban a sportpontszám átlaga tehát 2,54 -dal, míg a kontrollcsoportban 1,96-dal emelkedett.

A projekt végén az intervenciós csoportban szignifikáns változást mértünk a haskörfogatban, a csökkenés mértékének átlaga $4,93 \mathrm{~cm}(\mathrm{n}=14, \mathrm{Z}=-2,18, \mathrm{p}=$ $0,035)$, valamint a 12 percre számított futási távban $(\mathrm{n}=12, \mathrm{Z}=-2,624, \mathrm{p}=0,009)$. A résztvevők átlagosan 325 méterrel futottak többet, a kontrollcsoportban ilyen változást nem tudtunk kimutatni. Összehasonlítottuk a „Milyennek ítéli meg egészségi állapotát most?” kérdésre adott válaszok megoszlását azok körében, akik mindkét alkalommal válaszoltak erre a kérdésre $(n=51)$, és mind a két csoportban szignifikáns változást tapasztaltunk (Pearson-féle $\chi^{2}=26,592, \mathrm{df}=12, \mathrm{p}=0,009$, illetve Pearson-féle $\left.\chi^{2}=13,542, \mathrm{df}=6, \mathrm{p}=0,035\right)$. Az intervenciós csoportban a válaszadók 61,53\%-a (16 fó), a kontrollcsoportban 48\%-a (12 fö) számolt be kedvező irányú változásról (1. ábra).

Az egészségi állapot SF-36 kérdőívvel jellemzett 8 komponense közül az intervenciós csoport esetében 3 (érzelmi szerep, mentális egészség, általános egészség), a kontrollcsoportnál 5 (fizikai múködés, fizikai szerep, vitalitás, szociális múködés, általános egészség) komponensben történt statisztikailag szignifikáns, kedvező irányú változás a 3. táblázat szerint.

\section{Megbeszélés}

Eredményeinket elemezve arra a végkövetkeztetésre juthatunk, hogy programunk csak részben érte el céljait. Nem sikerült a tervezett 120 fó bevonása, noha a program indulását komoly (a célként kitűzött létszámot többszörösen meghaladó) érdeklődés övezte. Úgy tűnik, hogy a kissé közhelyes megállapítás - miszerint a páciensszerepet az orvosok, illetve egészségügyi dolgozók különösen nehezen fogadják el - még az egészségfejlesztés területén is érvényesül. Fontos tapasztalat az is, hogy egy rövid, mindössze 12 hónapos követéses vizsgálatnál is számítani kell komoly mértékű lemorzsolódásra. Egészségfejlesztési programunkba önkéntes alapon jelentkezhettek a résztvevők, intervenciót szervezni másképpen nem is lehetséges. Úgy tünik azonban, hogy az egyéni motiváció, a változtatás szándéka még nem elég, ez úgy is könnyen elmúlhat, ha a jelentkező anyagi kötelezettséget vállal [16]. Vizsgálatunk arra nem tért ki, mivel lehet fenntartani az életmód változtatásának elhatározását, annyit viszont kijelenthetünk, hogy a lehetőségek megteremtése és önköltséges áron történő felkínálása ehhez önmagában kevés. Sikeres programok szervezéséhez már a tervezési fázisban ki kell dolgozni azt a módszertant, amely megfelelő mértékben fenntartja a motivációt, erősíti az elhatározást. Ilyen lehet például egy-egy alkalomszerú (például havi) személyes egyeztetés a már elért eredményekről, rendszeres (például heti) emlékeztető e-mail vagy SMS, esetleg közösségi oldalon létrehozott tematikus csoport, ahol a résztvevók a program szervezőivel kommunikálhatnak. Mindez természetesen erőforrásokat igényel a kivitelezők részéről, ami viszont a kivitelezést nehezítheti meg [17-19].

Jelzés értékűnek tekinthetjük, hogy a programba elsősorban nók jelentkeztek, mintegy alátámasztva azt a sztereotípiát, hogy többet hajlandóak tenni egészségükért, mint a férfiak [20]. Mind a két nem átlagéletkora negyven év felett volt, ami szintén igazolja a korábbi megfigyeléseket, miszerint a fiatal felnőttkor vége, a kö- 
zépkor kezdete felé jelentkezik először komolyabb igény az egészségi állapot rendezésére, életmódváltásra [21]. Fiatalabb korban az igény feltehetőleg még nem fogalmazódik meg, ugyanakkor éppen a fizikai és szellemi (mentális) teljesítőképesség csúcsán kellene olyan programokat indítani, amelyek az állapot minél hosszabb ideig tartó megőrzését célozzák. Külön célzott populációnak kellene tekinteni a fiatal (45 év alatti) férfiakat, az általános népességből is közismert kedvezőtlenebb életkilátásaik okán, ami feltehetőleg egészségügyi dolgozók körében is hasonlóan rossz [22].

Tekintettel az önkéntes részvételre, valamint a kis elemszámra, mintánk prevalenciaadataiból túl messzire menő következtetéseket nem lehet levonni, elemzésük mégis egyfajta támpontot jelent az egészségügyi szektorban dolgozók egészség-magatartásával és egészségi állapotával kapcsolatban. Kedvező jelenségnek ítélhetjük, hogy a rendszeres dohányzás és a túlzott alkoholfogyasztás előfordulása is ritka volt. Ez a kép azonban feltehetően nem valós, korábbi felmérésekből, illetve akár a mindennapi tapasztalatainkból tudhatjuk, hogy a legális élvezeti szerekkel az egészségügyi dolgozók is rendszeresen élnek, mindenesetre kevésbé, mint az általános populáció $[23,24]$. Mind a táplálkozás, mind pedig a testmozgás tekintetében ugyanakkor kedvezőtlennek mondható kezdeti állapotot regisztráltunk. Hiába adták mintánk nagy részét egészségügyi dolgozók, táplálkozási és testmozgási szokásaik semmiben sem mutattak jobb képet, mint a hazai átlag [25]. A testmozgás területén jellemző, hogy az általunk kínált kedvező, önköltséges lehetőséggel sem éltek, ennek okait leginkább talán az időhiányban kereshetjük [26]. Vizsgálatunk alátámasztotta azt a feltevésünket is, miszerint az egészségügyi dolgozók is sokat használják a számítógépet, napi átlaga 4,14 óra volt. Ez felveti annak problémáját, hogy olyan okból is kialakulhatnak különböző mozgásszervi panaszok és betegségek, amelyre korábban az egészségügyben csak kevésbé gondoltunk (ülő munka). Sajnálatos módon a munkahelyi egészségmegőrzés hagyománya, illetve szokása hazánkban nem eléggé honosodott meg, noha elsősorban nyugat-európai és amerikai modellek igazolták, hogy akár a munkaidő rovására is érdemes prevenciós programokat szervezni, mert a munka hatékonyságának növekedésével, illetve a betegség miatti hiányzások csökkenésével jár [27-29].

Tizenkét esetben regisztráltunk magas vérnyomást (amely egyszeri mérés lévén nem jelent feltétlenül hypertoniát), de férfiak esetében az átlagérték is az úgynevezett magas-normális kategóriába esett. A BMI átlaga szintén a férfiaknál mutatott emelkedett értéket: ez a túlsúly felső határán mozgott. Mindezekből természetesen nem vonható le az az általánosító következtetés, hogy az egészségügyben dolgozó férfiak túlsúlyosak, illetve a vérnyomásuk magas, ugyanakkor jó beavatkozási pontként azonosítható, tekintettel a két paraméter között fennálló ismert összefüggésre, valamint arra, hogy a helyzet testmozgással is javítható [30].
Érdekes megfigyelés, hogy a továbbszámított testmozgásmutatónk (sportpontszám) mind a kontroll-, mind pedig az intervenciós csoportunkban emelkedett (kedvező irányú változást a diéta tekintetében csak az intervenciós csoporton belül figyeltünk meg). Úgy véljük, hogy a jelenség hátterében az állhat, hogy akár csak kontrollcsoportként csatlakozni egy egészségfejlesztési programhoz, kedvező irányú változást indíthat el. Ennek mértéke azonban nagyobb volt abban az esetben, ha valaki deklaráltan vállalta a sportolást. A testmozgás gyakoriságának fokozódása a diéta egészségesebb irányba történő elmozdulásával járt együtt, és ennek hatására észleltük a haskörfogat közel öt centiméteres csökkenését (csak az intervenciós csoportban). Ezen megfigyeléseink egybevágnak nemzetközi eredményekkel. Az elhízástudományi szakemberek szerint a legkisebb mértékű haskörfogat-csökkenés a szív-ér rendszeri betegségek kialakulási kockázatának mérséklődésével jár [31, 32].

A kedvező irányú változások az önértékelt egészségi állapotban nem tükröződtek: mind a kontroll-, mind pedig az intervenciós csoportban kedvező irányú változásokat regisztráltunk. A változás aránya azonban nagyobb mértékű volt az intervenciós csoportban, ahol a válaszolók több mint 60 százaléka jelzett kedvező irányú változást, míg a kontrollcsoportban ennek aránya kevesebb, mint 50\%. Továbbgondolásra érdemes eredményünk az is, hogy a kedvező irányú változások, úgy tưnik, más-más okból következtek be. Intervenciós csoportunk esetében az SF-36-skálák alapján inkább a mentális, míg a kontrollcsoport esetében inkább a fizikai komponensben beszélhetünk pozitív irányú változásról. Intervenciós programunk magyarázatként szolgálhat a jelenségre, hiszen elsősorban a mentálhigiénés tréningekkel, illetve a sportolási lehetőséggel éltek nagy számban a résztvevők, és az első intervenció egyértelmúen, míg a másik áttételesen, de szintén az önértékelt lelki egészség javításának irányába hat. Szem előtt kell tartani a hatás multiplikálódását is: a rendszeresen sportoló orvosok nagyobb arányban adnak életmódtanácsokat pácienseik részére [33].

Vizsgálatunk kis elemszáma, sajnos, nem engedi általános következtetések levonását. Noha a programot elsősorban a Semmelweis Egyetem egészségügyi munkát végző dolgozóinak hirdettük meg, az egyetemi csatornákon a lehetőség természetszerúleg nem egészségügyi dolgozókhoz, illetve hallgatókhoz is eljutott, így a teljes mintánkba nem csak egészségügyi dolgozók kerültek. További limitációt jelent, hogy az intervenciós szolgáltatások részvételi számai igen eltérőek voltak, és sokan kiléptek a vizsgálatból. Közbülső mérések nem történtek, így csak a kezdő és záró állapotfelmérésen résztvevőket tudtuk figyelembe venni.

Programunk egyike azon kezdeményezéseknek, amelyek célzottan a betegellátást nyújtó szektorban dolgozók egészségi állapotának javítását és vizsgálatát tüzték ki célul. Az orvosok és nővérek egészsége régóta képezi kutatások tárgyát, hazai viszonylatban azonban csak elvétve készültek a célcsoportra vonatkozó felmérések - külö- 
nösen nem követéses, illetve intervenciós vizsgálatok. Az egészségügyi dolgozókkal kapcsolatos vizsgálatokat, álláspontunk szerint, folytatni kell, de sokkal nagyobb hazai mintákon, szorosabb monitorozást alkalmazva. Így lehetôség nyílna a nagyobb nemzetközi tanulmányokkal történő összehasonlításra is. További konklúziónk, hogy érdemes volna fó célcsoportokat kijelölni, és célzottan őket vizsgálni. Fő feladatnak a 45 év alatti korosztály egészségmegőrzésének promócióját tartjuk.

\section{Következtetések}

Elmondhatjuk, hogy csakúgy, mint a dolgozó társadalom nagy részében, úgy az egészségügyi szférában sem fordítanak kellő idő́t arra a munkavállalók, hogy egészségük megőrzése érdekében valamilyen sporttevékenységet folytassanak. Elvégzett vizsgálataink alapján arra a megállapításra jutottunk, hogy bár a sportolás központi eleme az egészségfejlesztésnek, önmagában a mozgás megfelelő életmódváltás nélkül még nem elegendő. Szükséges volna mind az egyén, mind a munkáltató részéről az állandó motiváció fenntartása, hiszen egy egészséges, kiegyensúlyozott munkavállaló tud igazán aktív, felelősségteljes munkát végezni. Teljes körü egészségfejlesztési eredmény azonban természetesen csak komplex programmal és alapvető munkáltatói szemléletváltással érhető el, ezért lehetővé kell tenni a programokban dietetikai, valamint mentálhigiénés szakember igénybevételének lehetőségét is, hogy az előbb említett szempontok megfelelően érvényesüljenek.

Anyagi támogatás: A közlemény alapját képező egészségfejlesztési projektet a Semmelweis Egyetem Alumni Igazgatósága, valamint a projekt résztvevői finanszírozták. A projekt eredményeit jelen közleményben bemutató kutatómunka külön anyagi támogatásban nem részesült.

Szerzôi munkamegosztás: H. Á. kezdeményezte a közlemény alapját képező egészségfejlesztési projektet, amelynek megvalósításában T. A., H. Á., J. I., Gy. Zs. is részt vett. M. M. a jelen közleményhez szükséges szakirodalmi háttér gyújtését végezte. T. A., J. I., H. A. írta a Minta és módszer fejezetet. T. A., H. F. végezték a közleményhez szükséges statisztikai elemzéseket, írták az Eredmények fejezetet. T. A., M. M., Gy. Zs. írta a Következtetések fejezetet. Gy. Zs. végezte a kézirat végső áttekintését, korrektúrázását.

Érdekeltségek: A szerzőknek nincsenek érdekeltségeik.

\section{Irodalom}

[1] https://www.ksh.hu/docs/hun/xstadat/xstadat_eves/i_ fer001.html

[2] Balázs, P.: Physicians' workforce and the current impact of international migration in Hungary. [Orvosi létszámok és a nemzet- közi orvosmigráció aktuális hatása Magyarországon.] Orv. Hetil., 2012, 153(7), 250-256. [Hungarian]

[3] Schwarzwälder, S., Friedrich, D., Braeseke, G., et al. (eds.): Oc cupational Health and Safety Risks in the Healthcare Sector. Guide to prevention and good practice. Publications Office of the European Union, 2011.

[4] Jäger, M., Jordan, C., Theilmeier, A., et al.: Lumbar-load analysis of manual patient-handling activities for biomechanical overload prevention among healthcare workers. Ann. Occup. Hyg., 2013, $57(4), 528-544$.

[5] Landsbergis, P. A.: Occupational stress among health care workers: A test of the job demands-control model. J. Organ. Behav., 1988, 9(3), 217-239.

[6] Györffy, Zs., Ádám, Sz.: Somatic and mental morbidity of young female physicians. Does emotional exhaustion constitute the missing link? [Fiatal orvosnők testi-lelki egészsége. Az emocionális kimerülés a hiányzó láncszem?] Orv. Hetil., 2013, 154(1), 20-27. [Hungarian]

[7] European Agency for Safety and Health at Work: How to tackle psychosocial issues and reduce work-related stress. Office for Official Publications of the European Communities, Luxembourg, 2002

[8] Detre, Z.: Sport as a treatment of stress, anxiety, and depression. [Sporttal a stressz, a szorongás és a depresszió ellen.] Belügyi Szemle, 2007, 55(1), 29-49. [Hungarian]

[9] Peterson, U., Demerouti, E., Bergström, G., et al.: Burnout and physical and mental health among Swedish healthcare workers. J. Adv. Nurs., 2008, 62(1), 84-95.

[10] Dunn, P. M., Arnetz, B. B., Christensen, J. F. et al.: Meeting the imperative to improve physician well-being: Assessment of an innovative program. J. Gen. Intern. Med., 2007, 22(11), 15441552.

[11] Crane, M.: Why burned-out doctors get sued more often. Med. Econ., 1998, 75(10), 210-218.

[12] Cooper, K. H.: Aerobics. Bantam Books, New York, 1969.

[13] Godwin, M., Streight, S., Dyachuk, E., et al.: Testing the simple lifestyle indicator questionnaire: initial psychometric study. Can. Fam. Physician, 2008, 54(1), 76-77.

[14] Fagerström, K. O.: Measuring degree of physical dependence to tobacco smoking with reference to individualization of treatment. Addict. Behav., 1978, 3(3-4), 235-241.

[15] Ware, J. E. Jr., Sherbourne, C. D.: The MOS 36-item short-form health survey (SF-36). I. Conceptual framework and item selection. Med. Care, 1992, 30(6), 473-483.

[16] Pronk, N. P., Goodman, M. J., O'Connor, P. J., et al.: Relationship between modifiable health risks and short-term health care charges. JAMA,1999, 282(23), 2235-2239.

[17] Perez, A. P., Phillips, M. M., Cornell, C. E., et al.: Promoting dietary change among state health employees in Arkansas through a worksite wellness program: the Healthy Employee Lifestyle Program (HELP). Prev. Chronic Dis., 2009, 6(4), Al23.

[18] Global Recommendations on Physical Actvity for Health. WHO, Geneva, 2010.

[19] Moore, T. J., Alsabeeh, N., Apovian, C. M., et al.: Weight, blood pressure, and dietary benefits after 12 months of a web-based nutrition education program (DASH for health): longitudinal observational study. J. Med. Internet Res., 2008, 10(4), e52.

[20] Rurik, I., Szigethy, E., Langmár, Z.: Medical doctors in Hungary: 30 years after graduation. Data on lifestyle, morbidity, demography and differences between specialties. Cent. Eur. J. Public Health, 2014, 22(3), 183-188.

[21] McAuley, E., Mihalko, S. L., Bane, S. M.: Exercise and self-esteem in middle-aged adults: multidimensional relationships and physical fitness and self-efficacy influences. J. Behav. Med., 1997, $20(1), 67-83$.

[22] Kopp, M., Skrabski, Á.: Life expectations of the Hungarian population. [A magyar népesség életkilátásai.] Magy. Tud., 2007, 168(9), 1149-1153. [Hungarian] 
[23] Cooper, C. L., Rout, U., Faragher, B.: Mental health, job satisfaction, and job stress among general practitioners. BMJ, 1989, 298(6670), 366-370.

[24] Rosta, J., Aasland, O. G.: Changes in alcohol drinking patterns and their consequences among Norwegian doctors from 2000 to 2010: a longitudinal study based on national samples. Alcohol Alcohol., 2013, 48(1), 99-106.

[25] Central Statistical Office: European Health Interveiw Survey, 2014. [Központi Statisztikai Hivatal: Európai lakossági egészségfelmérés, 2014.] Statisztikai Tükör, 2015, 29, 1-9. [Hungarian]

[26] Visser, M. R., Smets, E. M. Oort, F. J., et al.: Stress, satisfaction and burnout among Dutch medical specialists. CMAJ, 2003, 168(3), 271-275.

[27] Pate, R. R., Pratt, M., Blair, S. N., et al.: Physical activity and public health. A recommendation from the Centers for Disease Control and Prevention and the American College of Sports Medicine. JAMA, 1995, 273(5), 402-407.

[28] Szmodis, M., Bosnyák, E., Bede, R., et al.: Hungarian Society of Sport Science: "Movement $=$ Health" program. A survey on the background of the physical performance of the Hungarian young generations. $[\mathrm{Az}$ MSTT Mozgás = Egészség Programjának magyarországi tapasztalatai - A fiatal generációk fizikai teljesítményének háttérvizsgálata.] Népegészségügy, 2013, 91(2), 130138. [Hungarian]
[29] Ács, P., Hécz, R., Paár, D., et al.: Value of fittnes - impact of physical inactivity on the national economy in Hungary. [A fittség $(\mathrm{m})$ értéke - a fizikai inaktivitás nemzetgazdasági terhei Magyarországon.] Közgazdasági Szemle, 2011, 58(7-8), 689-708. [Hungarian]

[30] Kaleta, D., Makowiec-Dabrowska, T., Jegier, A.: Occupational and leisure-time energy expenditure and body mass index. Int. J. Occup. Med. Environ. Health, 2007, 20(1), 9-16.

[31] Emmons, K. M., Linnan, L. A., Shadel, W. G., et al.: The Working Healthy Project: a worksite health-promotion trial targeting physical activity, diet, and smoking. J. Occup. Environ. Med., 1999, 41(7), 545-555.

[32] Ammerman, A. S., Lindquist, C. H., Lohr, K. N., et al.: The efficacy of behavioral interventions to modify dietary fat and fruit and vegetable intake: a review of the evidence. Prev. Med., 2002, 35(1), 25-41.

[33] Oberg, E. B., Frank, E.: Physicians' health practices strongly influence patient health practices. J. R. Coll. Physicians Edinb., 2009, 39(4), 290-291.

(Terebessy András dr., Budapest, Nagyvárad tér 4., 1089 e-mail: terebessy.andras@med.semmelweis-univ.hu)

\section{Ellen Notbohm-Veronica Zysk} EZEREGY NAGYSZERRUU ÖTLET

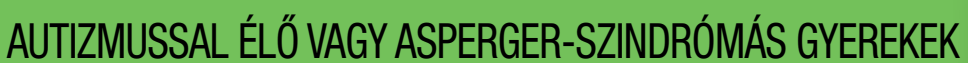
NEVELÉSÉHEZ ÉS TANÍTÁSÁHOZ

„Ha minden iskolában és családban a könyvben szereplő ötletek kis töredékét felhasználnák, beláthatatlan lehetöségek nyilinának meg elöttünk, hogy javítsuk az autizmussal vagy Asperger-szindrómával élö gyermekek életminōségét. Ez pedig csodálatos dolog!"

A könyv számtalan azonnal alkalmazható ötletet kínál szülőknek és nevelőknek az alábbi területeken:

- szenzoros integráció: fejlesztőfeladatok a szabadban és bent,

- kommunikáció: szóhasználat, hallás, vizualitás, környezet,

- viselkedés: tipikus viselkedési formák és kezelésük,

- mindennapi élet: ötletek a mindennapi szituációkhoz, a biztonság megteremtéséhez,

- szociális létezés: barátság, játék, kooperáció, érzelmek.

Dr. Temple Grandin 